
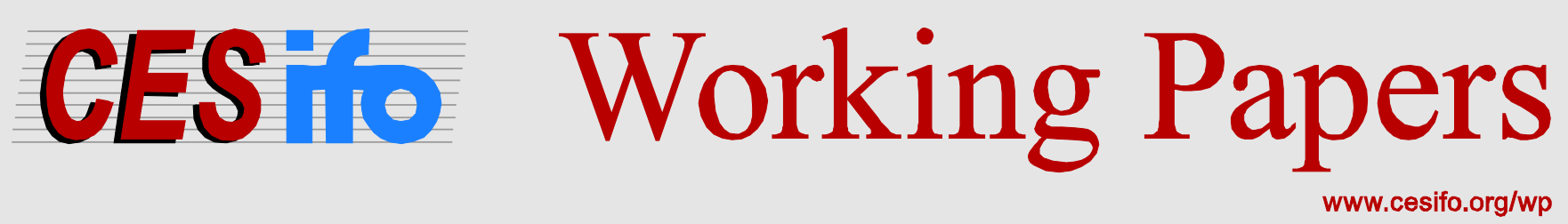

\title{
Corporate Deductibility Provisions and Managerial Incentives
}

\author{
Marko Koethenbuerger \\ Michael Stimmelmayr
}

CESIFO WORKING PAPER NO. 4549

CATEgORY 1: Public FinANCE

DECEMBER 2013

\footnotetext{
An electronic version of the paper may be downloaded

- from the SSRN website:

- from the RePEc website:

- from the CESifo website:

wWw.SSRN.com

Www.RePEc.org

www.CESifo-group.org/wp
}

\section{CESifo}




\title{
Corporate Deductibility Provisions and Managerial Incentives
}

\begin{abstract}
Using an agency model of firm behavior, the paper analyzes whether the cost of investment should be tax exempt. The findings suggest that, when managers engage in wasteful capital expenditures, welfare may decline if the cost of investment is tax deductible, as commonly advocated. The extent to which the return on investment should be taxed depends on how the internal provision of incentive pay and external monitoring by banks interact in constraining the manager and whether retained earnings or new share issues finance investments at the margin. The results are informative for the design of investment subsidies which might be integrated in corporate tax systems such as an Allowance for Corporate Equity or a cash-flow tax.
\end{abstract}

JEL-Code: H250, D210.

Keywords: corporate taxation, investment subsidies, corporate governance, delegated monitoring, incentive contract.

Marko Koethenbuerger

Department of Management, Technology and Economics / ETH Zurich

Weinbergstr. 35

Switzerland - 8092 Zurich

koethenbuerger@kof.ethz.ch
Michael Stimmelmayr

Department of Management, Technology and Economics / ETH Zurich

Weinbergstr. 35

Switzerland - 8092 Zurich

stimmelmayr@kof.ethz.ch

\section{December, 2013}

This is a revised version of the paper "Corporate Taxation and Corporate Governance". We are grateful to seminar and conference participants in Gothenburg, Maastricht, Magdeburg, Munich, Oxford, Stockholm and Vienna for their helpful comments. Financial support through a grant from the European Policy Research Network (EPRN grant \# 30570) and the German Science Foundation (DFG STI 619/1-1) is gratefully acknowledged. 


\section{Introduction}

The effects of corporate taxation on investment have been extensively discussed within the neoclassical model of firm behavior. ${ }^{1}$ The neoclassical framework treats the firm as a "black box", operating so as to maximize the firm value. It thereby disregards tensions between the interests of executives and those of shareholders that are central to the corporate governance literature (see Tirole, 2006). In this paper, we set up an agency model of firm behavior in which we analyze the fundamental question in corporate taxation of whether the cost of investment should be exempted from taxation. The issue sparks a huge literature in public economics which analyzes the role of immediate write-off provisions for investment expenses (R-based cash-flow tax) or a tax deductibility of the cost of finance (Allowance for Corporate Equity) in exempting the cost of investment (see, e.g., Auerbach, 2002, and Auerbach et al., 2010, for a review of the literature). ${ }^{2}$ All such policies effectively involve a tax on the marginal return on investment and a subsidy on the marginal cost of investment in equal proportions, thereby leaving investment choices undistorted. A full deductibility of either investment expenses or the cost of finance is efficient, absent agency problems. The paper shows that the conclusion may not hold in an agency model.

In the paper, managers and shareholders have diverging perceptions on the desirability of investment projects. Specifically, a manager has the opportunity to invest either in productive investment that yields a pecuniary return, capitalizing in the firm value, or in unproductive investments (pet-projects) that lead to a non-pecuniary return for the manager. The two different investment types are non-verifiable and thereby cannot be distinguished by the shareholders and the government. Thus, neither an incentive contract between the shareholders and the manager nor the tax system can perfectly control the manager's incentive and, thereby, induce him to abstain from wasteful capital expenditures. As a consequence, managers pay too little dividends compared with a situation where no agency problem exists between shareholders and managers (Jensen and Meckling, 1976). The prediction is in line with empirical findings, showing that over-investment of free cash flow is a systematic phenomenon. ${ }^{3}$

\footnotetext{
${ }^{1}$ See, for instance, King (1974), Auerbach (1979), Bradford (1981), Sinn (1991a) and, for a review of the literature, Auerbach (2002) and Auerbach et al. (2010).

${ }^{2}$ The ACE was first proposed by the Institute of Fiscal Studies (IFS, 1991, and Devereux and Feeman, 1991) and is related to the work by Boadway and Bruce (1984). A refined treatment can be found in, for example, Bond and Devereux (1995).

${ }^{3}$ Among others, Richardson (2006) finds that managers over-invest 20 per cent of positive free cash flow. Harford (1999) suggests that cash-rich firms are more likely to make acquisitions that subsequently experience
} 
We show that corporate deductibility provisions have ambiguous welfare implications. In particular, the welfare effects are sensitive to whether dividend distributions are made at the investment stage, i.e. whether the firm is cash constrained. With no cash distributions at the investment stage, deductibility provisions related to investment expenses or the cost of finance do not affect welfare. The provisions turn into a lump-sum subsidy with no capacity to improve efficiency.

With cash distributions at the investment stage the choice of the deductibility provision influences welfare. The welfare effects depend on the relative importance of the two managerial choice problems. Taking the choice of managerial perks in isolation, a less generous deductibility provision increases welfare. Intuitively, a lower deductibility rate lowers perk investment which positively influences shareholder wealth and tax revenues. As a counteracting effect, productive investment may drop as well which negatively affects shareholders and public revenues. Provided the latter response is not too strong, it is optimal not to allow for a deductibility provision.

The corporate tax and the dividend tax might be used in different ways in accommodating undesirable efficiency effects of changes in the deductibility rate with opposite implications for the optimal choice of the deductibility provision. For instance, a reduction in the deductibility rate in combination with a lower corporate tax rate, which is set so as to leave productive investment constant, unambiguously raises welfare. The reason is that the two adjustments in fiscal parameters reinforce each other in reducing managerial incentives to spend on perks. Thus, the absence of a deductibility provision promotes welfare. Differently, a higher deductibility rate increases productive and unproductive investments. When retained earnings are the marginal source of finance, a lower dividend tax reduces perk investments and leaves the amount of productive investments constant. As such, a higher deductibility rate in combination with a lower dividend tax, which is set so as to leave perk investments constant, increases welfare. The diverging efficiency effects of the corporate and dividend tax are due to the existence of perk investments and, thereby, do not exist in neoclassical models of firm behavior.

We consider two types of corporate governance systems in the model: incentive contracts, which shareholders offer to the manager, and bank monitoring. Banks are assumed to have a comparative advantage in monitoring (Diamond, 1984) and are able to reduce managerial

abnormal declines in operating performance. Dittmar and Mahrt-Smith (2007) provide similar evidence and relate the agency conflict to the quality of governance. They show that firms with poor corporate governance dissipate excess cash reserves more quickly on less profitable investments than with good corporate governance. 
incentives to spend on perks. We analyze the interaction between managerial ownership and bank monitoring and, in particular, how the two governance systems react to changes in the deductibility rate. For instance, we show that, provided banks view the two governance systems as (imperfect) substitutes and shareholders provide more high-powered incentive schemes in response to stronger managerial incentives to consume perks, a higher deductibility rate lowers welfare through adjustments in monitoring. The opposite conclusion holds when one of the two conditions does not hold.

\subsection{Literature review}

As mentioned above, our paper differs from the large body of public finance literature which typically abstracts from corporate agency problems (Auerbach, 2002; Hasset and Hubbard, 2002). An early exception is found in Kanniainen and Södersten (1994) who analyze the impact of bank monitoring on the response of firms to corporate taxes. They take the view that monitoring perfectly solves any conflict between shareholders and the management; hence, agency problems that result in diverging investment incentives are effectively absent in their analysis.

Only recently agency problems have made an explicit appearance in tax policy analysis. Desai et al. (2007) show that, when managers can divert resources, corporate taxes interact with the level of investment and rent diversion. As a consequence, corporate taxes may amplify the agency problem. ${ }^{4}$ Kanniainen (1999) and Chetty and Saez (2010) consider the effects of dividend and corporate taxes in an agency model of free cash flow. The contributions do not consider a deductibility provision for investment expenses or the cost of finance. ${ }^{5}$ Schindler and Schjelderup (2012) analyze the effects of corporate taxes on tax avoidance behavior when there is a conflict of interest among shareholders. The work does not analyze the efficiency effects of deductibility provisions. Also, our analysis builds on externalities managers exert on shareholders and on externalities private stakeholders of the firm exert on the public budget rather than on externalities between different groups of shareholders.

Haufler and Schjelderup (2000) show that a cash-flow tax and an ACE system ${ }^{6}$ lower welfare

\footnotetext{
${ }^{4}$ In their model the agency problem takes the form of managerial theft. Hence, resources leave the firm instead of staying within the firm as in our model (with empire-building investments). From that perspective, the work of Desai et al. (2007) is more targeted to economies with poor corporate governance systems. Besides corporate taxes, Desai et al. also consider tax enforcement policies. See also Desai and Dharmapala (2006) and Crocker and Slemrod (2005) on tax enforcement policies when managers and shareholders have misaligned interests.

${ }^{5}$ Related contributions on dividend taxation include Gordon and Dietz (2009) and Korinek and Stiglitz (2009).

${ }^{6}$ Haufler and Schjelderup (2000) explicitly consider a cash-flow tax which is equivalent to an ACE system in their setting.
} 
once firms are able to shift profits outside the jurisdiction. The finding relies on inefficiencies associated with decentralized tax choices rather than on corporate agency problems. Keuschnigg and Ribi (2013) show that for cash-constrained firms a cash-flow tax and an ACE tax system are not investment neutral and that bank monitoring influences the welfare effects of corporate taxation. Internal agency conflicts are absent. Finally, there is a small body of literature on the interaction between different corporate governance systems. Most related to our paper, John and Kedia (2006) analyze the interaction between bank monitoring and managerial ownership, albeit in a different set-up than presented in the paper. To the best of our knowledge, the effects of taxes and, in particular, of deductibility provisions when internal and external governance systems are used simultaneously have not been analyzed so far. ${ }^{7}$

The paper proceeds as follows. In Section 2 we set up an agency model of free cash flow with endogenous incentive pay. In Section 3 we characterize the shareholders' choice of incentive pay and the firm's investment behavior. In Section 4 we turn to the welfare effects of deductibility provisions. In Section 5 we introduce delegated monitoring by banks and analyze the welfare implications of how bank monitoring interacts with corporate deductibility provisions. Finally, we provide a summary of the results and offer some concluding remarks in Section 6 .

\section{Model}

Consider a model of corporate investment in which the firm is a price taker and the manager of the firm can make two types of investments: productive investments $I$ and unproductive investments (pet-projects) $J$. In period 1 , the firm might have some cash holdings $X \geq 0$ that can be paid out as dividends, $D_{1}$, or can be invested (un)productively. ${ }^{8}$ In period 2 , the firm produces output using the technology $F(I)=f(I)+\epsilon . \epsilon$ is a stochastic term which is normally distributed with $E(\epsilon)=0$ and $\operatorname{Var}(\epsilon)=\sigma^{2} .{ }^{9}$ The deterministic part of production $f(I)$ is strictly increasing and concave in the amount of productive investments. At the end of period 2, the firm is liquidated and all liquidation proceeds net of taxes are paid to shareholders. Expected

\footnotetext{
${ }^{7}$ Chetty and Saez (2010) consider incentive contracts and the choice of monitoring by shareholders and analyze how the two internal governance mechanisms react to taxes. Deductibility provisions are not considered.

${ }^{8}$ Although the investment model is static, we consider two periods to reflect the fact that the firm has a past in our model (most notably due to the existence of some cash holdings) and to formally distinguish between dividend payments that are made at different times.

${ }^{9}$ Profits and dividends may become negative with a normally distributed stochastic term. We implicity consider only cases in which such a scenario does not arise.
} 
dividend payments are

$$
E\left(D_{2}\right)=(1-\tau) f(I)+\tau z r K+\tau K
$$

where $K=I+J$ denotes the aggregate amount of investment. The first term in (1) denotes the net-of-tax return on productive investments $I$. The second term gives the tax savings due to a deductibility of the cost of finance. The variable $z \in[0,1]$ indicates the extent to which the cost of capital is deductible from the corporate tax base. When the $z$-parameter equals one, the cost of finance is fully tax deductible as is the case under the Allowance for Corporate Equity (ACE) system. If the cost is not tax deductible, implying $z=0$, the tax systems resembles the Comprehensive Business Income Tax $(\mathrm{CBIT}) \cdot{ }^{10} \mathrm{An}$ alternative way of considering a deductibility provision is to allow for an immediate write-off of investment expenses (R-based cash flow tax). An immediate expensing of investment has equivalent effects on investment and welfare as a deductibility of the cost of investment finance. ${ }^{11}$ Thus, the subsequent results can be interchangeably expressed in terms of the deductibility of the cost of finance or of investment expenses. Capital is assumed to fully depreciate after use in production. The third term in (1) represents the tax savings due to capital depreciation.

At the shareholder level, dividends are taxed at rate $\tau_{d} \cdot{ }^{12}$ We assume that corporate taxes cannot be credited against dividend taxes. We should note that the results also hold when corporate taxes cannot be fully credited against the shareholder's personal income tax. Tax systems that entail an incomplete offset of corporate taxes at the shareholder level are implemented in a number of countries, including Germany, the US, and the UK.

Shareholders must be indifferent between providing equity and buying government bonds that yield a rate of return of $r$. The respective arbitrage condition is

$$
r V_{t}=\left(1-\tau_{d}\right) D_{t}+\left(V_{t+1}-V_{t}-V_{t}^{N}\right)
$$

where $V_{t}^{N}$ denotes the amount of new share issues in period $t$ and $V_{t}$ denotes the firm value in period $t$. Since the firm is liquidated at the end of period 2 and new share issues are not optimal

\footnotetext{
${ }^{10}$ The CBIT was advocated by the US Treasury (1992).

${ }^{11}$ Such a provision can be considered by subtracting the term $\tilde{z} K(1+r)$ from the firm's tax base in period 2 and eliminating the depreciation term $\tau K$ in (1). If $\tilde{z}=1$, the tax system offers a full immediate write-off.

${ }^{12}$ In our setting, shares are held until the end of the second period when the firm is finally liquidated and liquidation proceeds are paid out to shareholders in form of dividends. Hence, a realization-based capital gains tax, as applied in practice, does not influence corporate investment behaviour and tax revenues. In fact, the lock-in effect, inherent to realization-based capital gains taxes, provides incentives to hold shares with accrued capital gains as long as possible, as assumed in the model.
} 
in period 2, the arbitrage condition (2) yields after recursive substitution ${ }^{13}$

$$
(1+r) V_{1}=\left(1-\tau_{d}\right)\left(D_{1}+\frac{D_{2}}{1+r}\right)-V_{1}^{N}
$$

$(1+r) V_{1}$ is the value of the firm at the end of period 1 which is subsequently denoted by $V_{1}^{e}$.

Shareholders and the manager have non-congruent investment incentives. The manager invests either productively or unproductively. While productive investments $I$ yield a pecuniary net-of-tax return of $(1-\tau) f(I)$, which capitalizes in the firm value, pet projects $J$ solely generate a private benefit $g(J)$ for the manager, where the utility function $g(J)$ is strictly increasing and concave. ${ }^{14}$ One may view $J$ as empire-building investments or investments that imply a quiet life for managers. In either case, capital $J$ remains inside the firm and is part of the firm's balance sheet. ${ }^{15}$

Shareholders prefer a level of investment that maximizes their wealth (3), implying $J=0$. Corporate agency problems arise when investment decisions are delegated to a manager and both investments, $I$ and $J$, are non-verifiable, i.e. neither shareholders nor the government is able to verify (at reasonable costs) whether the investments are productive or perks. ${ }^{16}$ This has two implications. First, the tax system cannot distinguish between the two investment types. The deductibility of the cost of finance as well as depreciation applies to both types; see (1). Secondly, shareholders cannot design incentive schemes that are conditioned on the level of $J$, ensuring $J=0$. Still, shareholders might use equity-based incentive contracts to partially address the agency problem. We assume that shareholders offer a fraction $\alpha$ of the firm to the manager in addition to a fixed wage payment $a$. Manager utility over discounted income $w=\alpha V_{1}^{e}+\frac{a}{1+r}$ is $u(w)$ with $u^{\prime}(w)>0>u^{\prime \prime}(w)$. Thus, expected manager utility over income and perk investment is

$$
U=E(u(w))+\frac{g(J)}{1+r} .
$$

Assuming that utility over income is exponential, manager utility (4) can be rewritten in mean-

\footnotetext{
${ }^{13}$ Any new share issues in period 2 would imply that these funds are distributed at the end of period 2 , net of dividend tax. Shareholders wealth and manager utility would drop in response.

${ }^{14}$ The sharp distinction between the two investment types is made for simplicity. The paper's results equally hold when pet-projects $J$ are also productive, but sufficiently less productive than investments $I$. Also, to exclude hurdle rates related to the rate of return on investment to solve the agency problem, we could additionally allow both returns to be stochastic.

${ }^{15}$ Note, we do not view $J$ as resources that are directly diverted by the manager. We thereby implicitly assume "mature" corporate governance structures to be in place which preclude theft on the part of the manager. See, for instance, Desai et al. (2007) on managers' incentives to divert resources in low-quality governance economies.

${ }^{16}$ This implies that the input-output relation $y=f(I)$ is not verifiable such that the inverse $f^{-1}(y)$ cannot be used to contract on $I$.
} 
variance form

$$
U=E(w)-\rho \operatorname{Var}(w)+\frac{g(J)}{1+r}, \quad \rho>0 .
$$

Using (1) and (3), the income variance is

$$
\operatorname{Var}(w)=\left(\alpha \frac{(1-\tau)\left(1-\tau_{d}\right)}{1+r}\right)^{2} \sigma^{2} .
$$

The manager's reservation utility is normalized at zero which yields the participation constraint $U \geq 0$. Since manager remuneration is costly to shareholders, the manager's participation constraint will hold as an equality. Inserting $U=0$ into external shareholder wealth $(1-\alpha) V_{1}^{e}$, while noting (5) and $w=\alpha V_{1}^{e}+\frac{a}{1+r}$, yields

$$
(1-\alpha) V_{1}^{e}=E\left(V_{1}^{e}\right)+\frac{a}{1+r}-\rho \operatorname{Var}(w)+\frac{g(J)}{1+r} .
$$

The sharing parameter $\alpha$ does not explicitly enter the right-hand side of (7). Intuitively, shareholders become residual claimants which effectively induces them to maximize the sum of their wealth and manager utility when choosing manager remuneration. In this environment, the shareholders' choice of $\alpha$ follows from the well-known incentive-insurance trade-off (e.g., Holmstrom, 1979). A higher $\alpha$ tends to align incentives between shareholders and the manager, but at the same time exposes the risk-averse manager to more risk. The latter effect is costly to shareholders since it requires a higher compensatory fixed wage payment to satisfy $U=0$.

The timing of events is as follows: In period 1, external shareholders choose the incentive contract and hire a manager. At the end of period 1, the manager chooses the level of investment $I$ and pet projects $J$ and shareholders receive dividend payments $D_{1} \geq 0$. In period 2, the production shock is realized, production takes place, taxes are collected, shareholders receive dividend payments $D_{2}$, and the manager receives perk utility $g(J)$.

\section{Investment policy and incentive contracts}

Investment behavior of the firm crucially depends on the source of finance. New share issue and retained earnings are two source of funds that are frequently elaborated in the literature. The two modes of finance might mirror the life-cycle of a firm. A firm might have insufficient internal funds relative to its investment opportunities and uses new share issue as a marginal source of funds at an early stage of its life. Once it matures and generates sufficient profits, it retains part of these to finance investment at the margin (see Auerbach, 2002, for instance). In 
what follows we also consider a third possibility, namely that the firm has insufficient internal funds and might be constrained in receiving external funds. In this case, the firm is finance constrained. ${ }^{17}$ Auerbach and Hasset (2003) find that over the period 1981-98 roughly $63 \%$ of US firms have not not initiated dividend distributions. These account for $9 \%$ of the equity value in the sample, suggesting that these are mostly young, non-mature firms for which finance constraints might be more severe than for mature firms. Also, finance constraints, as modeled below, are able to explain the extensive margin of firm dividend responses to the 2003 dividend tax cut in the U.S., see Chetty and Saez (2010).

\subsection{Finance constraints}

When the firm is finance constrained, the manager invests all funds $X$ and thereby sets firstperiod dividend payments to zero. The manager maximizes (5) subject to $D_{1}=X-I-J=0$, $V_{1}^{N}=0$ and (1), taking $\alpha$ as given. The first-order condition for $I$ is

$$
\alpha\left(1-\tau_{d}\right)(1-\tau) f^{\prime}(I)=g^{\prime}(X-I)
$$

where $J=X-I$ is residually determined. The level of $D_{1}$ is zero if $\left(1-\tau_{d}\right)(1-\tau) f^{\prime}(I)+z \tau r+\tau>$ $1+r$ holds at the optimum prescribed by (8). ${ }^{18}$ Combining (8) with the inequality, the absence of first-period distributions is more likely the lower initial cash holdings $X$. Following (8), the manager weighs the additional second-period dividend payments when investing productively against the loss in private utility from perks. Since the subsidy $z$ is granted to both investment types, the relative attractiveness of productive and perk investment is not affected by $z$. Hence, the subsidy leaves investment incentives unchanged. Further, (8) shows that the investment pattern become more skewed towards productive investments following a rise in $\alpha$, as intended.

Shareholders choose the fraction of the firm allocated to the manager so as to maximize (7), anticipating the investment choices of the manager. Setting $D_{1}=0$ and invoking the envelope theorem, the first-order condition for the choice of $\alpha$ is

$$
(1-\alpha) \frac{\left(1-\tau_{d}\right)(1-\tau) f^{\prime}(I)}{1+r} \frac{d I}{d \alpha}=2 \alpha \rho\left(\frac{\left(1-\tau_{d}\right)(1-\tau)}{1+r}\right)^{2} \sigma^{2} .
$$

A higher level of $\alpha$ induces the manager to invest more productively and less unproductively. Shareholders set $\alpha$ so as to align the disciplining effect to the cost of exposing the manager to

\footnotetext{
${ }^{17}$ See, e.g., Fazzari et al. (1988) and Kaplan and Zingales (1997) on the empirics of finance constraints. The literature generally shows that finance constraints are of empirical relevance.

${ }^{18}$ Productive capital, hence, earns an excess return which is a common feature of constrained investment models. See, e.g., Holmstrom and Tirole (1997).
} 
more risk, which needs to be compensated by a higher fixed wage payment. ${ }^{19}$ The deductibility parameter does not directly enter (9). Also, following (8), the investment choice does not vary with $z$. Hence, the level of productive investment, $I$, and its response to $\alpha, d I / d \alpha$, are unaffected by $z$ and so is the optimal level of $\alpha$, c.f. (9).

Lemma 1: When the firm is financially constrained, i.e. $D_{1}=0$ and $V_{1}^{N}=0$, investment behavior and the sharing parameter $\alpha$ are independent of $z$.

\subsection{No finance constraints}

We now allow firms to use new share issues and retained earnings as the marginal source of finance. With new share issues, first-period dividend payments are zero $D_{1}=0$ and investments are financed by issuing new shares, i.e $V_{1}^{N}>0$ and $d V_{1}^{N}=d K$. The first-order conditions for $I$ and $J$ are

(a) $-1+\frac{1-\tau_{d}}{1+r}\left((1-\tau) f^{\prime}(I)+z \tau r+\tau\right)=0$

(b) $\alpha\left(-1+\frac{1-\tau_{d}}{1+r}(z \tau r+\tau)\right)+\frac{g^{\prime}(J)}{1+r} \quad=0$.

Productive investment yields an increase in dividend payout in period 2 consisting of the net-oftax return on the productive investment and the tax advantage resulting from the deductibility of the cost of equity finance. At the optimum, the marginal benefit equals the loss in share value (for existing shares) in period 1 , as shown by the first-order condition (10a). Since the benefits and costs of productive investments fully capitalize in firm value, investment incentives of the manager and shareholders are perfectly aligned. The amount of $I$ coincides with the level preferred by shareholders.

The manager invests in pet projects up to the point where the reduction in share value equals the combined rise in second period distributions and in the utility of pet projects, see (10b). Second-period distributions rise due to tax savings that follow from the deductibility of the cost of equity finance and the depreciation allowance. As the benefit of perks does not capitalize in firm value, pet projects create a wedge between the manager's investment incentives and the shareholders' interest. Consequently, the manager pays out too little dividends in order to finance his own projects - a finding that is in line with the free cash flow hypothesis of Jensen and Meckling (1976).

\footnotetext{
${ }^{19}$ The fixed wage payment is determined residually and is set so as to satisfy the manager participation constraint $U=0$.
} 
Using retained earnings implies that the amount of new share issue is zero $V_{1}^{N}=0$ and first-period dividend payments adjust at the margin, i.e. $D_{1}=X-K>0$ and $-d D_{1}=d K{ }^{20}$ The first-order conditions for investment choices are

$\begin{array}{lll}\text { (a) } & -1+\frac{1}{1+r}\left((1-\tau) f^{\prime}(I)+z \tau r+\tau\right) & =0 \\ \text { (b) } & \alpha\left(1-\tau_{d}\right)\left(-1+\frac{1}{1+r}(z \tau r+\tau)\right)+\frac{g^{\prime}(J)}{1+r} & =0 .\end{array}$

The difference between (10) and (11) is that, with retained earnings, the government shares in the reduction of first-period dividend payments at rate $\tau_{d}$. Most notably, this implies that the government shares symmetrically in the costs and benefits of productive investments which makes productive investment incentives independent of the dividend tax, see Auerbach (1979).

Despite the difference in first-order conditions with new share issues and retentions, we find identical qualitative investment responses to changes in $\alpha$ and $z$ :

$$
\frac{\partial I^{i}}{\partial z}>0, \quad \frac{\partial J^{i}}{\partial z}>0, \quad \frac{\partial I^{i}}{\partial \alpha}=0 \quad \text { and } \quad \frac{\partial J^{i}}{\partial \alpha}<0, \quad i=n, r .
$$

The superscript $i=n, r$ denotes new share issues $(n)$ and the use of retained earnings $(r)$ as the marginal source of funds. A higher deductibility rate lowers the cost of investment under both financing regimes which raises investment levels. As shown above, incentives to invest productively are aligned between the manager and shareholders which implies that the level of productive investments is independent of $\alpha$, provided $\alpha>0$. Differently, a higher sharing parameter reduces unproductive investments since the manager participates in a larger fraction of the costs of perks.

The board of shareholders choose the sharing parameter $\alpha$ so as to maximize (7), anticipating the investment choices of the manager. Assuming that new share issues are the marginal source of funds and invoking the envelope theorem, the first-order condition for the choice of $\alpha$ is

$$
(1-\alpha)\left(-1+\frac{1-\tau_{d}}{1+r}(\tau r z+\tau)\right) \frac{\partial J^{n}}{\partial \alpha}=2 \rho \alpha\left(\frac{\left(1-\tau_{d}\right)(1-\tau)}{1+r}\right)^{2} \sigma^{2}
$$

which implicitly defines the optimal value of $\alpha^{n}$ as a function of $z$. The marginal benefit of incentive pay in form of lower perks and its positive effect on firm value is equated to the marginal cost due to a higher fluctuation of managerial income that needs to be compensated by a higher fixed wage. Likewise, with retained earnings as the marginal source of funds the optimal sharing parameter satisfies

$$
\left(1-\tau_{d}\right)(1-\alpha)\left(-1+\frac{1}{1+r}(\tau r z+\tau)\right) \frac{\partial J^{r}}{\partial \alpha}=2 \rho \alpha\left(\frac{\left(1-\tau_{d}\right)(1-\tau)}{1+r}\right)^{2} \sigma^{2},
$$

\footnotetext{
${ }^{20}$ Note, with dividend taxation a firm will not issue equity and distribute dividends simultaneously (see, e.g., Sinn, 1987, 1991b).
} 
which gives $\alpha^{r}$ as an implicit function of $z$. Differentiating (13) and (14) with respect to $z$ yields

$$
\frac{d \alpha^{n}}{d z}=(1-\alpha)\left\{\left(1-\tau_{d}\right)\left(\frac{\tau r}{1+r} \frac{\partial J^{n}}{\partial z}\right) \frac{\partial J^{n}}{\partial \alpha}+\left(-1+\frac{1-\tau_{d}}{1+r}(\tau r z+\tau)\right) \frac{\partial^{2} J^{n}}{\partial \alpha \partial z}\right\} \frac{1}{\Delta^{n}}
$$

and

$$
\frac{d \alpha^{r}}{d z}=\left(1-\tau_{d}\right)(1-\alpha)\left\{\left(\frac{\tau r}{1+r} \frac{\partial J^{r}}{\partial z}\right) \frac{\partial J^{r}}{\partial \alpha}+\left(-1+\frac{1}{1+r}(\tau r z+\tau)\right) \frac{\partial^{2} J^{r}}{\partial \alpha \partial z}\right\} \frac{1}{\Delta^{r}}
$$

where $\Delta^{i}>0$ holds by the second-order condition for the choice of $\alpha^{i}, i=n, r$. The contract responses (15) and (16) have two important elements in common. The first term in curly brackets reflects the direct impact of the deductibility provision on incentive pay. A higher $z$ increases the cost of using high-powered incentive schemes. More precisely, a lower $J$ also lowers the amount of tax subsidies the firm receives and this effect becomes stronger the higher $z$. In response, shareholders lower $\alpha$ when the deductibility provision becomes more generous. Second, a rise in $z$ influences the sensitivity of the perk response to the incentive wage $\partial^{2} J^{i} / \partial \alpha \partial z$, as captured by the second term in curly brackets. As shown in the Appendix, the sign of the cross derivative is ambiguous, but almost aligned across the two financing regimes. Importantly, the effect is of second order relative to the direct effect $z$ exerts on $J$. Thus, the effect on $\alpha$ and thereby on $J$ will not neutralize the direct effect a higher $z$ has on $J$. Hence,

Lemma 2: When the firm uses new share issues or retained earnings to finance investments, i.e. $D_{1}>0$ or $V_{1}^{N}>0$, the subsidy rate $z$ influences investment behavior directly and also through the sharing parameter $\alpha$. In particular,

$$
\frac{d J^{i}}{d z}=\left.\frac{\partial J^{i}}{\partial z}\right|_{d \alpha^{i}=0}+\frac{\partial J^{i}}{\partial \alpha^{i}} \frac{d \alpha^{i}}{d z}>0 \quad \text { and } \quad \frac{d I^{i}}{d z}=\left.\frac{\partial I^{i}}{\partial z}\right|_{d \alpha^{i}=0}<0, \quad i=n, r .
$$

\section{Welfare implications}

Subsequently, we analyze the efficiency implications of changes in the corporate tax base. We thus assume that tax revenues are rebated to tax payers as a lump sum. The government sets $z$ so as to maximize the sum of private welfare (comprising firm value and utility from perks) and discounted tax revenues, anticipating how investment choices respond to the tax system. 
Formally, the government solves ${ }^{21}$

$$
\max _{z \in[0,1]} \quad E(W)=E\left(V_{1}^{e}\right)+\frac{g(J)}{1+r}+\frac{E(T)}{1+r},
$$

where

$$
E(T)=\tau(f(I)-(z r+1) K)+\tau_{d}\left(D_{1}+\frac{D_{2}}{1+r}\right)
$$

Second-period dividend payments are given by (1), investment levels follow from (10) or (11) and the incentive contract satisfies (13) or (14).

\section{$4.1 \quad$ Finance constraints}

We first turn to the case in which first-period dividend payments are zero, effectively assuming that $X$ is not too large. Following Lemma 1, investment behavior is unaffected by the deductibility rate $z$. The total amount of investment is constant $(d I+d J=0)$ and, since the deductibility provision is granted to both investments, $z$ does not influence the structure of investment. Further, the share $\alpha$ does not vary with the deductibility rate. As such, changes in $z$ only exert mechanical tax revenue effects and the deductibility provision is effectively a lump-sum subsidy. We can immediately conclude:

Proposition 1: Assume first-period dividend distributions and new share issues are zero, i.e. the firm is financially constrained. Then, for any level of the corporate tax and the dividend $\operatorname{tax}\left(\tau, \tau_{d}\right) \in(0,1)^{2}$, small changes in the deductibility rate $z \in[0,1]$ are welfare neutral.

Proposition 1 states an equivalence result: Provided all internal funds are used for investments, a tax system that allows for the deductibility of the cost of finance (ACE), and a tax system that does not include such a deductibility provision (as a CBIT does) are equivalent in the model, for a given choice of the corporate tax rate. The finding contrasts previous literature which shows that, when interests between managers and shareholders are aligned, a tax exemption of the cost of finance $(z=1)$ improves efficiency of investment choices and increases welfare.

The tax subsidy, which is granted by an ACE, provides liquidity to the firm. Unless lenders are willing to use future tax subsidies as pledgeable income, the tax subsidy does not relax the

\footnotetext{
${ }^{21}$ We restrict the choice of $z$ to the unit interval which is the relevant range for implementing an ACE or CBIT system as polar cases. We may thus pick constrained optimal solutions. The characterization of unconstrained optimal deductibility rates straightforwardly follows from the respective welfare analysis.
} 
finance constraint, as assumed here. Differently, a R-based cash-flow tax gives the tax subsidy at the time when the investment is made, thereby potentially relaxing the finance constraint. Hence, Proposition 1 appears to be of relevance for tax systems with a deferred expensing of the cost of investment.

\subsection{No finance constraints}

Assuming new share issues to be the marginal source of funds, the change in expected welfare (18) following a rise in $z$ is

$$
\begin{aligned}
\frac{d E\left(W^{n}\right)}{d z}= & (1-\alpha)\left(-1+\frac{1-\tau_{d}}{1+r} \tau(z r+1)\right) \frac{\partial J^{n}}{\partial z}+\frac{1}{1+r}\left(\tau\left(f^{\prime}\left(I^{n}\right)-r z-1\right) \frac{d I^{n}}{d z}-\tau(r z+1) \frac{d J^{n}}{d z}\right) \\
& +\frac{\tau_{d}}{1+r}\left(\left((1-\tau) f^{\prime}\left(I^{n}\right)+\tau(r z+1)\right) \frac{d I^{n}}{d z}+\tau(r z+1) \frac{d J^{n}}{d z}\right) .
\end{aligned}
$$

The first term depicts the change in private welfare. Productive investments do not influence private welfare which follows from an application of the envelope theorem. The manager does not account for the effect of the cost of perks on external shareholders, thereby generating an externality at a rate $1-\alpha$ of the change in firm value. A higher deductibility rate magnifies the externality, thus producing a negative first-order effect on private welfare. The first-order welfare effect is not caused by any adjustment in the incentive contract. Since shareholders effectively maximize private utility, marginal changes in $\alpha$ have no consequences for the induced change in private utility. It is only the direct effect of $z$ on perk investments which underlies the first-order welfare effect. Thereby, private choices are suboptimal which creates a corrective role for tax policy. The second term in (20) depicts the fiscal externality which a change in productive and perk investments exerts on corporate tax revenues. The effects of the two investment responses on fiscal income are of opposite sign. A more generous deductibility provision negatively affects revenues due to the induced rise in perks, but simultaneously increases revenues through the rise in productive investments. To see the latter, note that, following (10) and (11), the term $f^{\prime}(I)-r z-1$ is positive for $\tau_{d}>0$. The third term gives the change in dividend tax revenues. A rise in the two types of investments yields higher dividend tax revenues either due to a higher output or higher tax subsidies which shareholders receive in form of dividend payments. The fiscal externality that works through dividend tax revenues is thus positive. 
With retentions as the marginal source of finance, the welfare implications of a rise in $z$ are

$$
\begin{aligned}
\frac{d E\left(W^{r}\right)}{d z}= & (1-\alpha)\left(1-\tau_{d}\right)\left(-1+\frac{1}{1+r} \tau(z r+1)\right) \frac{\partial J^{r}}{\partial z}+\frac{1}{1+r}\left(\tau\left(f^{\prime}\left(I^{r}\right)-r z-1\right) \frac{d I^{r}}{d z}\right. \\
& \left.-\tau(r z+1) \frac{d J^{r}}{d z}\right)+\tau_{d}\left(-1+\frac{1}{1+r}(\tau(r z+1))\right) \frac{d J^{r}}{d z}
\end{aligned}
$$

The welfare effect is similar in structure to (20) with two differences. First, the dividend tax also subsidizes the marginal cost of finance (taking the form of reduced first-period dividend payments). As a consequence, the first-order effect on private welfare is a fraction $1-\tau_{d}$ of the reduction in external shareholder wealth gross of dividend taxes. Second, different to (20), dividend tax revenues do not change with the amount of productive investment. The manager maximizes the stream of dividends when choosing $I$, c.f. (11a). By an application of the envelope theorem, the effects of changes in $I$ on dividend tax revenues vanish.

\subsubsection{Only corporate taxation $\left(\tau_{d}=0\right)$}

To unravel the welfare effects of deductibility provision in a transparent and simple form, we first abstract from dividend taxation. When $\tau_{d}=0$, using new share issues or retained earnings as the marginal source of funds yields identical implications for investment policy and the incentive contract, c.f. (10), (11), (13) and (14). ${ }^{22}$

At this point it might be instructive to characterize the optimal choice of $z$ in the absence of an agency problem, i.e. in the absence of verifiability problems. When $J \equiv 0$, the welfare terms (20) and (21) only comprise the fiscal externality due to changes in productive investments. Following (10) and (11) evaluated at $\tau_{d}=0$, the externality is positive for $z<1$ and zero at $z=1$. Thus, setting $z=1$ eliminates the fiscal externality for any choice of $\tau$. Intuitively, allowing for a full deductibility of the cost of finance insulates the return on investment from the tax rate which leaves investment incentives undistorted, i.e. $f^{\prime}(I)=1+r$ (Boadway and Bruce, 1984; Devereux and Freeman, 1991). Moreover, the efficiency cost of the corporate tax $\tau$ vanishes as well, and the tax rate can be set at any feasible level to collect revenues on rents.

In the presence of an agency conflict a higher $z$ exerts counteracting effects on welfare, c.f. (20) and (21). As verified above, the positive tax base effect due to changes in productive investments is zero at $z=1$. This precludes $z=1$ to be the efficient choice of the deductibility rate. Intuitively, at $z=1$ the return and cost of productive investment are fully included in the

\footnotetext{
${ }^{22}$ To save on notation, we omit the index for the financing regime as long as we keep $\tau_{d}=0$.
} 
tax base, and so a marginal downward deviation of $z$ exerts no behavioral revenue effect through changes in productive investments. The remaining welfare effect in (20) and (21) work through the adjustment in perk investments that are negative in sign. In sum,

Proposition 2: Assume firms use new share issues or retentions as the marginal source of funds and $\tau_{d}=0$. For any level of the corporate tax rate $\tau \in(0,1)$, a corporate tax system that allows for a full deductibility of the cost of equity finance $(z=1)$ is welfare-dominated by a tax system that entails a marginally lower deductibility rate $z$.

Proposition 2 is uninformative as to the extent to which $z$ can be lowered. For $z<1$, a lower $z$ continues to generate the efficiency benefit of lower perk investment which, however, must be weighed against the Harberger deadweight loss due to lower productive investments. Straightforwardly, provided the productive investment response is not too strong compared to the response in perks, it is optimal to set $z=0 .{ }^{23}$ Otherwise, the optimal choice of the deductibility rate is interior $z \in(0,1)$, balancing the efficiency effects of the two investment types.

A natural question is whether the corporate tax $\tau$ can be used in addition to $z$ to enhance efficiency of investment choices. Following (10) or (11), the corporate tax has countervailing effects on investment incentives

$$
\frac{\partial I}{\partial \tau}<0 \quad \text { if } z \in[0,1) \quad \text { and } \quad \frac{\partial J}{\partial \tau}>0 .
$$

A rise in the corporate tax rate increases the value of the deductibility provision and lowers the net-of-tax return on productive investments. The latter effect undermines incentives to invest productively when $z \in[0,1)$, while incentives to invest unproductively become stronger, given the rise in the tax subsidy.

Consider a simultaneous reduction in $z$ and $\tau$ so as to keep the incentives to invest productively constant. The reform leaves the level of productive investments unaffected, and so only singles out welfare effects that result from changes in perk investments. Following (10) or (11), the policy requires perturbations in $z$ and $\tau$ that satisfy $d \tau=[\tau(1-\tau) /(1-z)] d z$. The

\footnotetext{
${ }^{23}$ This applies when, for example, the curvature of $f(I)$ is sufficiently pronounced relative to the curvature of $g(J)$. Note from (10) or (11), $f^{\prime \prime}(I)$ and $g^{\prime \prime}(J)$ influence the investment responses to changes in $z$.
} 
associated welfare change is

$$
\left.\frac{d E(W)}{d \tau}\right|_{d I=0} \frac{d \tau}{d z}+\left.\frac{d E(W)}{d z}\right|_{d I=0} .
$$

The last term is given by (20) or (21), evaluated at $d I=0$ and $\tau_{d}=0$. It is negative in sign. The welfare change due to the tax rate adjustment follows from differentiating (18), while accounting for $d I=0$ and $\tau_{d}=0$, which gives

$$
\left.\frac{d E(W)}{d \tau}\right|_{d I=0}=(1-\alpha)\left(-1+\frac{\tau(r z+1)}{1+r}\right) \frac{\partial J}{\partial \tau}-\frac{\tau(r z+1)}{1+r} \frac{d J}{d \tau} .
$$

The welfare change (24) reflects the negative first-order effect of $z$ on private welfare, due to the pre-existing distortion in the level of perk investment, and the negative fiscal externality higher perk investments exert on the public budget. As a consequence, welfare strictly increases in response to the tax-cut cum base-broadening reform. ${ }^{24}$ The less favorable deductibility rate lowers the amount of perk investments, an effect that is reinforced by the drop in the corporate tax rate which reduces the tax value of the deductibility provision. Hence,

Proposition 3: Consider $\tau_{d}=0$ and a tax system $(\tau, z) \in(0,1)^{2}$. (i) The corporate tax decreases productive investments and tends to increase perk investments, thereby distorting the structure of investment. (ii) With new share issues and retained earnings as the marginal source of finance, there exists a tax-cut cum base-broadening reform (marginally lowering $z$ and $\tau$ so as to keep productive investment constant) that increases welfare.

Proposition 3 predicts that a marginally lower $z$ with an appropriate adjustment in $\tau$ increases welfare. By a continuity argument, the tax-cut cum base-broadening reform can be continued until the deductibility provision related to equity finance is abolished. ${ }^{25}$

\footnotetext{
${ }^{24}$ As shown in Appendix A.2, the effect of a higher corporate tax on the sharing parameter encompasses the effect a higher deductibility parameter has on $\alpha$. Recall, $\tau$ and $z$ are identical in their effects on the perk subsidy $\tau z r$. A higher corporate tax has the additional effect of lowering the income variance of the manager (6) by shifting some of the income risk onto the public budget. The effect makes it less costly for shareholder to use incentive pay and the potentially positive effect of $\tau$ on $\alpha$ becomes stronger than the effect of $z$ on $\alpha$. For simplicity, we assume that the insurance effect on $\alpha$ does not overturn the sign of the direct effect of $\tau$ on perks. Note, the condition is only sufficient for $d J / d \tau>0$.

${ }^{25}$ The required post-reform corporate tax rate does not violate the non-negativity constraint. Comparing (10a) and (11a) for $z \in(0,1)$ and for $z=0$, the post-reform tax rate $\tilde{\tau}$ that keeps productive investment incentives unchanged when eliminating $z \in(0,1)$ is

$$
\tilde{\tau}=\frac{(1+r)(1-\tau)-(1+r-\tau(r z+1))}{(1-\tau)-(1+r-\tau(r z+1))}
$$

where $\tau$ is the pre-reform tax rate. Note, we have $\tilde{\tau} \in(0,1)$ when $\tau \in(0,1)$ and $\tilde{\tau}=0$ only when $\tau=0$.
} 


\subsubsection{Corporate and dividend taxation}

With dividend taxes, the welfare results presented so far need to be modified when new share issues are the marginal source of funds. Note, with retained earnings as the marginal source of funds the investment responses that are crucial to Proposition 2 and 3 are not altered and hence Proposition 2 and 3 equally apply in the presence of dividend taxation, c.f. (11). However, the investment responses do not always extend to situations in which firms rely on new share issues to finance investments. In particular, using (10), productive investment is distorted even when $z=1$, i.e. $f^{\prime}(I)>1+r$. The reason is that the government taxes the return to investment by the corporate tax and the dividend tax, but does not allow for a symmetric tax treatment of the cost of investment. A deductibility rate $z=1$ neutralizes the distortionary effect of corporate taxation. However, productive investments are still downward distorted by the dividend tax. As such, a deductibility rate $z>1$ is needed to ensure tax neutrality. The finding implies that Proposition 2 does not hold with $\tau_{d}>0$. A marginal downward deviation away from $z=1$ lowers both types of investments and the overall welfare effect depends on the relative magnitude of the two responses. A straightforward implication is that $z=1$ might yield higher welfare than a deductibility rate $z<1$. A tax system that exempts the cost of investment (ACE system or a R-based cash flow tax) might be preferred to a tax system that taxes the full return on investment (as a CBIT system does). Still, both types of investment react asymmetrically to a higher corporate tax rate. Thus, a tax-cut cum base-broadening reform that keeps productive investment incentives constant raises welfare, similar to Proposition 3 that assumes $\tau_{d}=0 .{ }^{26}$

Moreover, the dividend tax influences investments differently under the two financing regimes. Using (10) and (11), the responses are

$$
\frac{\partial I^{n}}{\partial \tau_{d}}<0, \quad \frac{\partial J^{n}}{\partial \tau_{d}}<0, \quad \frac{\partial I^{r}}{\partial \tau_{d}}=0 \quad \text { and } \quad \frac{\partial J^{r}}{\partial \tau_{d}}>0
$$

The cost of new share issues is not included in the dividend tax base. The dividend tax only taxes the pecuniary return to investment and the tax subsidies the firm receives, c.f. (10). Hence, the tax treatment thereby undermines incentives to invest productively, as predicted by the 'old' view of dividend taxation, and undermines incentives to spend on perks. When investments are financed via retained earnings, the government participates in the costs and benefits of investing productively at rate $\tau_{d}$, but participates only in the costs of investing unproductively, c.f. (11). The dividend tax is non-distortionary with respect to productive investments, as predicted by

\footnotetext{
${ }^{26}$ As implied by (10), the exact change in the corporate tax rate $d \tau / d z$ must now account for the dividend tax.
} 
the 'new' view of dividend taxation (Auerbach, 1979), and strengthens incentives to spend on perks.

The question which is of interest here is whether dividend taxes may play an efficiencyenhancing role similar to corporate taxes in designing the corporate tax base. It becomes apparent from (25) that dividend taxes are generally not able to discriminate between the two investment types if new share issues serve as the marginal source of funds. Both investments are discouraged by a higher tax rate $\tau_{d}$ and, thus, a lower $\tau_{d}$ will not eliminate the adverse efficiency effects of a lower $z$ on $I$, without creating additional efficiency losses which follow from adjustments in the level of perks. Differently, when the firm uses retained earnings at the margin, a higher dividend tax leaves productive investments unchanged, but discourages perk investments. In this case, the welfare effects of a higher $\tau_{d}$ are

$$
\frac{d E\left(W^{r}\right)}{d \tau_{d}}=-\frac{1}{1+r} \tau(r z+1) \frac{d J^{r}}{d \tau_{d}}+\tau_{d}\left(-1+\frac{1}{1+r} \tau(r z+1)\right) \frac{d J^{r}}{d \tau_{d}} .
$$

Different to the welfare implications of the deductibility rate and the corporate tax, the dividend tax exerts no first-order effect on private welfare despite the pre-existing distortion in investments (Chetty and Saez, 2010). Intuitively, a higher dividend tax and a lower sharing parameter lower the stake the manager has in the firm. Hence, the dividend tax and the incentive contract are equivalent in their effects on investments, c.f. (11). Since the sharing parameter is optimized, changes in the dividend tax rate do not influence private welfare. Further, since productive investments are not distorted by dividend taxation, the overall welfare effect only follows from the negative fiscal externality that is associated with changes in the amount of perks. ${ }^{27}$

Following (21), (25) and (26), a more generous deductibility provision $z \in[0,1)$ when combined with a reduction in the dividend tax, so as to leave the level of perks constant, increases welfare by

$$
\left.\frac{d E\left(W^{r}\right)}{d \tau_{d}}\right|_{d J^{r}=0} \frac{d \tau_{d}}{d z}+\left.\frac{d E\left(W^{r}\right)}{d z}\right|_{d J^{r}=0}>0 .
$$

From (11b), the required change in $\tau_{d}$ following a rise in $z$ is

$$
\frac{d \tau_{d}}{d z}=-\frac{\left(1-\tau_{d}\right) \tau r}{1+r-\tau(z r+1)}<0
$$

Thus,

\footnotetext{
${ }^{27}$ The result that dividend taxes are distortionary in a model of free cash flow with retained earnings as the marginal source of funds is related to Kanniainen (1999) and Chetty and Saez (2010). As shown in Appendix A.3, this requires the managerial insurance effect of a higher dividend tax to be sufficiently small which we assume here.
} 
Proposition 4: Assume investments are financed by retained earnings at the margin and $\left(z, \tau, \tau_{d}\right) \in[0,1) \times(0,1)^{2}$. (i) A higher dividend tax does not influence productive investments, but tends to increase perks. (ii) A rise in the deductibility rate $z$ combined with a reduction in the dividend tax $\tau_{d}$, so as to leave incentives to spend on perks unchanged, raises welfare.

Corporate and dividend taxes have effects on investments different to the ones known from neoclassical models of firm behavior. ${ }^{28}$ These effects allow the adverse effects of changes in the definition of the corporate tax base to be neutralized with quite different implications for the type of corporate tax system. An ACE system is efficiency enhancing when corporate tax rate adjustments are used, while a CBIT is generically optimal with dividend tax adjustments. Which tax system yields higher welfare depends on the efficiency effects that are associated with corporate and dividend tax changes. Recall, the two tax reforms outlined in Proposition 3 and 4 make the corporate investment structure more efficient, albeit in different ways. A lower deductibility rate coupled with a lower corporate tax rate reduces the manager's return to perk investments $J$ while a higher deductibility rate in combination with a lower dividend tax increases the managerial return to productive investments $I$. The changes in the managerial rate of return most notably depend on the curvature of the production function $f(I)$ and of the utility function $g(J)$, both determining the responsiveness of investments and welfare to changes in the tax system, c.f. (11).

\section{$5 \quad$ Bank monitoring}

So far, we have assumed that firms do not resort to corporate debt to finance investments. In reality, firms do have a significant level of debt on the balance sheet. It might be used to finance inframarginal investments, while in particular mature firms use retained earnings to finance marginal investments (Auerbach and Hasset, 2003). Subsequently, we accommodate the empirical observation by assuming that the firm has an exogenous level of debt $B$ on the balance sheet. ${ }^{29}$ The interest rate on debt is $\tilde{r}$ which alters second-period dividend payments (1) and

\footnotetext{
${ }^{28}$ Straightforwardly, perks, which are crucial to Proposition 3 and 4 , are absent in neoclassical investment models.

${ }^{29}$ Corporate debt may ameliorate agency problems in models of free cash flow. Debt effectively mortgages the normal return on investment that must be paid out to debt claimants, thereby reducing the free cash flow available for perks (Jensen, 1986, 1993; Grossman and Hart, 1982). The threat of firm liquidation inherent to debt finance provides similar incentives for perk spending (Aghion and Bolton, 1992; Bolton and Scharfstein, 1996). In our setting, the incentive device is only partly effective. For any amount of cash left in the firm (i.e. after debt
} 
tax revenues (19) to

$$
E\left(D_{2}\right)=(1-\tau) f(I)+\tau(r z(K-B))+\tau K-(1+\tilde{r}) B
$$

and

$$
E(T)=\tau(f(I)-z r(K-B)-K)+\tau_{d}\left(D_{1}-\frac{D_{2}}{1+r}\right) .
$$

$K-B>0$ is the equity base of the firm (after first-period dividends are paid out). $K>B$ implies that the firm has some corporate debt that is used to finance inframarginal investments while marginal investments are financed by retained earnings.

Besides providing funds, banks are of value to shareholders due to their monitoring capacity, see Diamond (1984) and Holmstrom and Tirole (1997), for instance. Monitoring restrains the empire-building tendencies by the manager as captured by $g(J) m^{-1}, m>1 .^{30}$ The formulation might reflect the fact that monitoring increases the probability that the bank obtains verifiable information on the productivity of the investment, which negatively impacts the manager, or, relatedly, that the manager must exert more effort in hiding perk investments in the presence of monitoring (Tirole, 2006). Shareholders value bank monitoring in general. Delegated monitoring has an advantage to shareholders that cannot be replicated by the incentive contract shareholders offer to the manager. Intuitively, incentive pay exposes the risk-averse manager to more income fluctuation which needs to be compensated by shareholders. Monitoring equally aligns incentives, but without exposing the manager to more risk. As will become clear below, this creates scope for shareholder wealth to be rising in the extent of bank monitoring in the presence of an incentive contract.

Monitoring is costly to banks and banks are only incentivized to engage in monitoring if the interest rate on corporate debt will be adjusted accordingly. We assume that the interest rate $\tilde{r}$ is given by the sum of a base interest rate and a surcharge for monitoring, $\tilde{r}=r+\omega m$. The surcharge is determined in the competitive market for monitored debt. ${ }^{31}$

The sequence of decisions is as follows. In period 1, external shareholders choose the incentive

payment), the manager will invest some funds in unproductive investments. Thus, even with endogenous debt capital, the disciplining effect of corporate debt will not perfectly curb empire-building tendencies.

${ }^{30}$ The formulation on how monitoring lowers perk utility is without loss of generality.

${ }^{31}$ Different interpretations on how a debt contract that specifies $(m, \tilde{r})$ is enforceable are possible. We might assume that monitoring is verifiable and, thereby, a debt contract that specifies the level of monitoring is enforceable. Alternatively, we might also assume that monitoring is not verifiable but observable. In this environment, contracts might be self enforcing due to relationship banking or due to reputational concerns for future relationships of shareholders and of the bank with other market participants, provided monitoring and interest payments are observable to outsiders. See Sharpe (1990), among others. 
contract and hire a manager. Simultaneous to the contract choice, shareholders sign a contract $(m, \tilde{r})$ with the bank and the bank decides on the level of monitoring. At the end of period 1, the manager chooses the level of investments $I$ and pet projects $J$ and shareholders receive dividend payments $D_{1}$. In period 2, the production shock is realized, production takes place, taxes are collected, the firm pays principal and interest to the bank, shareholders receive dividend payments $D_{2}$, and the manager receives perk utility $g(J) m^{-1}$.

\subsection{Investment policy, incentive contracts and monitoring}

Investment choices follow from (11a) and (11b) with $g^{\prime}(J) m^{-1}$ replacing $g^{\prime}(J)$. Differentiation yields

$$
\frac{\partial I}{\partial m}=0 \quad \text { and } \quad \frac{\partial J}{\partial m}=\frac{1+r}{m} \frac{g^{\prime}(J)}{g^{\prime \prime}(J)}<0
$$

Given the investment response and the objective function of shareholders (7) (with $g(J) m^{-1}$ replacing $g(J)$ ), the shareholders' marginal willingness to pay for bank monitoring, given $\alpha \in$ $(0,1)$, is

$$
-\frac{g(J)}{(1+r) m^{2}}+(1-\alpha)\left(1-\tau_{d}\right)\left(-1+\frac{\tau z r}{1+r}\right) \frac{\partial J}{\partial m} .
$$

Since the manager's participation constraint must be satisfied, shareholders account for the negative effect of monitoring on manager utility, c.f. (7). This is guaranteed by an appropriate adjustment in the amount of the fixed wage $a$. When the marginal willingness is positive, shareholders will find it optimal to have some level of monitored debt on the balance sheet and to use incentive contracts and monitoring simultaneously. To create scope for monitored debt to play a role, we assume (31) to be positive. The bank receives a payment $(1+\tilde{r}) B$ from the firm while its refinancing costs are $(1+r) B$. Hence, bank profits are

$$
(1+\tilde{r}) B-(1+r) B-c(m, \alpha) \quad \text { with } \quad c(m, \alpha)=0.5 m^{2} \hat{c}(\alpha) .
$$

The cost of monitoring might depend on $\alpha$. We allow $\hat{c}^{\prime}(\alpha) \gtreqless 0$. For instance, monitoring may be easier for banks when internal governance mechanisms are stronger and, for instance, a more transparent internal documentation and evaluation process for new investment projects makes it easier for banks to detect perks. ${ }^{32}$ In this case, $\hat{c}^{\prime}(\alpha)<0$. Alternatively, perk investments may differ with respect to the ease with which banks can identify their perk character. Managers will first choose perk investments that are less easily identifiable as perks. In a firm with strong

\footnotetext{
${ }^{32}$ The view taken here is that the use of incentive pay and other internal governance systems such as internal accounting requirements is positively correlated.
} 
internal governance, it might thus be more costly for banks to achieve the same disciplining effect on the manager, i.e. $\hat{c}^{\prime}(\alpha)>0$.

Using (32) and $\tilde{r}=r+\omega m$, the first-order condition for the level of monitoring is

$$
\omega B-m \hat{c}(\alpha)=0
$$

which yields the bank's best response $m^{*}(\alpha)=\omega B / \hat{c}(\alpha)$ with slope

$$
\frac{d m^{*}(\alpha)}{d \alpha}=-\frac{\omega B \hat{c}^{\prime}(\alpha)}{\hat{c}(\alpha)^{2}} \gtreqless 0 \quad \Leftrightarrow \quad \hat{c}^{\prime}(\alpha) \lesseqgtr 0 .
$$

For a given level of monitoring, shareholders choose the incentive contract by maximizing (7), anticipating the investment choices of the manager. Using $d D_{1}=-d K$ and (28) and invoking the envelope theorem, the first-order condition qualitatively coincides with (14) with $g^{\prime}(J) m^{-1}$ replacing $g^{\prime}(J)$. The first-order condition (14) now implicitly defines the shareholders' best response, $\alpha^{*}(m, z)$. It is straightforward to show that differentiating (14) w.r.t. $\alpha$ and $z$, while noting the manager's investment responses, yields expression (16) as the slope of the shareholders' best response $\partial \alpha^{*}(m, z) / \partial z$. It follows that the implications of changes in $z$ on investment, for a given level of $m$, are the same as summarized in Lemma 2.

The Nash equilibrium in the choice of the two governance mechanisms are given by the values $\alpha^{* *}$ and $m^{* *}$ that are mutual best responses, i.e. $\alpha^{* *}=\alpha^{*}\left(m^{* *}, z\right)$ and $m^{* *}=m^{*}\left(\alpha^{* *}\right) \cdot{ }^{33}$ With local stability of the Nash equilibrium, the sign of the change in $\alpha^{* *}$ in response to a hike in $z$ follows from $\partial \alpha^{*}(m, z) / \partial z$ and the sign of the change in $m^{* *}$ from $d m^{*}(\alpha) / d \alpha$, implying that the change $\partial \alpha^{*}(m, z) / \partial m$ does not influence the qualitative changes in $\alpha^{* *}$ and $m^{* *}{ }^{34}$ Intuitively, a rise in $z$ has a direct effect on $\alpha$ which changes the monitoring intensity as implied by the slope of the bank's best response. Due to the local stability of the Nash equilibrium, any subsequent repercussions will not overturn the first-round adjustments in the level of monitoring and in the sharing rule.

Using (34), we can summarize the behavior of shareholders and of the bank as follows:

\footnotetext{
${ }^{33}$ Existence of a Nash equilibrium is guaranteed provided the objective functions of shareholders and of the bank are quasi-concave in the respective choice variable, $\alpha$ or $m$, and that both objective functions are continuous in $\alpha$ and $m$. See Vives (2000), for instance. All conditions are fulfilled except of the quasi-concavity of the shareholder objective function which we assume throughout. In order to perform meaningful comparative static analysis, we assume uniqueness of the Nash equilibrium.

${ }^{34}$ Local stability requires $\left|\partial \alpha^{*}\left(m^{* *}, z\right) / \partial m\right|\left|d m^{*}\left(\alpha^{* *}\right) / d \alpha\right|<1$ which in general holds by an appropriate scaling of the cost of monitoring $c(m, \alpha)$, for instance.
} 
Lemma 3: (i) A rise in the deductibility rate increases (decreases) the equilibrium value $\alpha^{* *}$ provided the shareholders' best response slopes upward (downward), i.e. $\partial \alpha^{*}\left(m^{* *}, z\right) / \partial z>(<)$ 0. (ii) A higher deductibility rate $z$ increases (decreases) the equilibrium value of monitoring $m^{* *}$ if $\hat{c}^{\prime}\left(\alpha^{* *}\right) \partial \alpha^{*}\left(m^{* *}, z\right) / \partial z<(>) 0$.

The behavioural response $\partial \alpha^{*}(m, z) / \partial z$ is ambiguous in sign. Given the discussion following (16), the sign of $\partial \alpha^{*}(m, z) / \partial z$ is determined by two potentially counteracting effects. First, a more generous deductibility rate incentivizes shareholders to become more lax in the provision of incentives to reduce perks in order to receive more subsidy payments. Second, for a variety of commonly used preference functions (including exponential, Cobb-Douglas and iso-elastic utility) shareholders provide more high-powered incentive schemes in order to counteract the stronger incentives by the manger to spend on perks following a rise in $z .^{35}$

\subsection{Welfare implications}

Welfare comprises expected shareholder wealth, manager utility, bank profits and tax revenues:

$$
E(W)=E\left(V_{1}^{e}\right)+\frac{g(J)}{1+r}+\frac{(\tilde{r}-r) B-c(m, \alpha)}{1+r}+\frac{E(T)}{1+r},
$$

where

$$
E(T)=\tau(f(I)-z r(K-B)-K)+\tau_{d}\left(D_{1}+\frac{D_{2}}{1+r}\right) .
$$

Dividend payments are given by (28). With bank monitoring, perturbations in $z$ do not only affect welfare due to changes in investments, both directly and through adjustments in the incentive contract, but also through the effects on bank behaviour. The former welfare effects follow from (21). The additional welfare effect due to adjustments in bank monitoring is

$$
\begin{aligned}
\frac{\partial E(W)}{\partial m} \frac{d m^{* *}}{d z}= & \left\{-\frac{g(J)}{(1+r) m^{2}}+(1-\alpha)\left(1-\tau_{d}\right)\left(-1+\frac{1}{1+r}(z \tau r+\tau)\right) \frac{\partial J}{\partial m}-m \hat{c}(\alpha)\right. \\
& \left.-\frac{1}{1+r}(r \tau z+\tau) \frac{\partial J}{\partial m}+\tau_{d}\left(-1+\frac{1}{1+r}(r \tau z+\tau)\right) \frac{\partial J}{\partial m}\right\} \frac{d m^{* *}}{d z} .
\end{aligned}
$$

The first line depicts the change in private welfare. With a competitive market for banking, the marginal willingness to pay for monitoring, as given by (31), is equated to the marginal costs banks incur and, as a consequence, the terms in the first line vanish. The effect might be surprising, given that manager utility is negatively affected by monitoring and that external

\footnotetext{
${ }^{35}$ For these preference functions $g^{\prime \prime \prime}>0$ which provides a counteracting force to the mechanical effect of a higher $z$ on incentive provision. See Appendix A1.
} 
shareholders only care about their wealth $(1-\alpha) V_{1}^{e}$. However, managers have a fixed outside option $(U=0)$ which, as shown above, turns shareholders into residual claimants of private welfare in the economy. The effect on manager utility is thus captured by the marginal willingness to pay, c.f. (31), and monitoring does not exert an externality on private welfare. The welfare effects of monitoring are only due to fiscal externalities, as depicted by the second line of (37). A higher level of monitoring reduces investment subsidies and initiates more dividend distributions in the first period. Both corporate and dividend tax revenues rise in response. Consequently, the sign of the partial welfare effect (37) depends on how a higher deductibility rate influences monitoring. ${ }^{36}$ Implied by Lemma 3 , the effect depends on $\operatorname{sign}\left\{\partial \alpha^{*}\left(m^{* *}, z\right) / \partial z\right\}$ and on $\operatorname{sign}\left\{\hat{c}^{\prime}\left(\alpha^{* *}\right)\right\}$. Hence,

Proposition 5: A higher deductibility rate increases (decreases) welfare through adjustments in the level of bank monitoring if $\hat{c}^{\prime}\left(\alpha^{* *}\right) \partial \alpha^{*}\left(m^{* *}, z\right) / \partial z<(>) 0$.

Illustratively, consider the case that shareholders provide more high-powered incentives when the tax system incentivizes the manager to invest more resources unproductively $\left(\partial \alpha^{*}\left(m^{* *}, z\right) / \partial z>\right.$ $0)$. Provided banks view internal and external governance mechanisms as (imperfect) substitutes $\left(\hat{c}^{\prime}\left(\alpha^{* *}\right)>0\right)$, a more generous deductibility provision lowers welfare through the response in bank behavior. The partial welfare effect complements the welfare effects (21), pointing to $z=0$ as being the (constrained) optimal choice of the corporate tax base. Differently, when internal and external governance mechanisms are complements from the bank's perspective $\left(\hat{c}^{\prime}\left(\alpha^{* *}\right)<0\right)$, the welfare effect in (37) is negative in sign and, when combined with the marginal efficiency effect (21), a deductibility rate $z=1$ might be the (constrained) optimal policy.

Two final comments are informative at this point. First, with finance constraints, monitoring influences the investment choice of the managers and the sharing parameter as given by the appropriately adjusted first-order condition (8) and (9), respectively. In the extended model, the two first-order conditions continue to be independent of $z$ and so is the level of welfare. As such, Proposition 1 also applies with monitoring. Second, the basic adjustments in the level of monitoring are independent of whether the dividend tax subsidizes the cost of investment in the

\footnotetext{
${ }^{36}$ Hence, when the firm uses direct loans by outside investors instead of monitored debt, the welfare effects of deductibility provisions are identical to the effects summarized in the previous section.
} 
first period. ${ }^{37}$ Thus, Proposition 5 equally holds when new share issues are the marginal source of funds.

\section{Concluding remarks}

This paper analyzes the efficiency effects of corporate deductibility provisions in a model of free cash flow with endogenous managerial ownership and delegated monitoring. One of our findings is that an efficient tax system may not allow for a full deduction of the cost of investment. The result has relevance for the tax policy discussion in many countries that have introduced or consider introducing an ACE (see, e.g., Devereux and De Mooij, 2009). One of the implications of the analysis is that a switch to an ACE system increases investment, but may reduce welfare.

Our analysis can usefully be extended along several dimensions. For instance, one may consider output-enhancing effort provision by the manager in addition to investments as the manager's choice variables. Further, the model analyzes the effects of deductibility provisions on investment choices. The model thereby focuses on the question of whether tax systems such as an ACE, a CBIT or a R-based cash-flow tax ensure investment efficiency. The issue of whether these tax systems ensure finance efficiency is not addressed in the paper. Most notably, this would require to endogenize the use of corporate debt in the model. Finally, we abstract from coordination problems between shareholders. When only a subset of shareholders (active shareholders) decide on the incentive contract, the first-order externality on private welfare will magnify and so will the demand for corrective policy. A similar conclusion applies to bank monitoring which will be inefficient in the absence of taxes provided only a subset of shareholders is active. We leave a formal analysis of these and other interesting extensions to future research.

\section{A Appendix: Response of the sharing parameter $\alpha$}

\section{A.1 Changes in the deductibility rate $z$}

(15) and (16) show that the response of the sharing rate $\alpha$ to a higher $z$ depends on the cross derivative $\partial^{2} J^{i} / \partial \alpha \partial z, i=n, r$. From (10b) and (11b), the cross derivatives in the two financing

\footnotetext{
${ }^{37}$ Note, with new share issues the welfare terms corresponding to the second line in (37) read
}

$$
-\frac{1-\tau_{d}}{1+r}(r \tau z+\tau) \frac{\partial J}{\partial m} \frac{d m^{* *}}{d z} .
$$

The fiscal externality of more intense monitoring is positive and the total welfare effect depends on $\operatorname{sign}\left\{d m^{* *} / d z\right\}$, as above. 
regimes are

$$
\frac{\partial^{2} J^{n}}{\partial \alpha \partial z}=\left(1-\tau^{d}\right) \frac{\tau r}{1+r}\left(\frac{-g^{\prime \prime}\left(J^{n}\right)}{1+r}\right)^{-1}+\left(-1+\frac{1-\tau_{d}}{1+r}(\tau r z+\tau)\right)\left(\frac{-g^{\prime \prime}\left(J^{n}\right)}{1+r}\right)^{-2} \frac{g^{\prime \prime \prime}\left(J^{n}\right)}{1+r} \frac{\partial J^{n}}{\partial z}
$$

and

$$
\frac{\partial^{2} J^{r}}{\partial \alpha \partial z}=\left(1-\tau_{d}\right)\left(\frac{\tau r}{1+r}\left(\frac{-g^{\prime \prime}\left(J^{r}\right)}{1+r}\right)^{-1}+\left(-1+\frac{\tau r z+\tau}{1+r}\right)\left(\frac{-g^{\prime \prime}\left(J^{r}\right)}{1+r}\right)^{-2} \frac{g^{\prime \prime \prime}\left(J^{r}\right)}{1+r} \frac{\partial J^{r}}{\partial z}\right)
$$

Since $-1+\frac{1}{1+r}(\tau r z+\tau)<0,-1+\frac{1-\tau_{d}}{1+r}(\tau r z+\tau)<0$ and $\partial J^{i} / \partial \alpha<0$, both cross derivatives are positive when $g^{\prime \prime \prime}\left(J^{i}\right)$ is not too positive. Evaluating the plausibility of this condition, note that $g^{\prime \prime \prime}\left(J^{i}\right)$ is positive for a wide class of preference functions including Cobb-Douglas, iso-elastic, and exponential preferences. Thus, we can conclude that $d \alpha^{i} / d z$ is ambiguous in sign for many widely used preference functions.

\section{A.2 Changes in the corporate tax rate $\tau$}

Differentiating (13) and (14) w.r.t. $\tau$ yields

$$
\begin{aligned}
\frac{d \alpha^{n}}{d \tau} & =\left\{(1-\alpha)\left(\left(1-\tau_{d}\right) \frac{z r+1}{1+r} \frac{\partial J^{n}}{\partial \alpha}+\left(-1+\frac{1-\tau_{d}}{1+r}(\tau r z+\tau)\right) \frac{\partial^{2} J^{n}}{\partial \alpha \partial \tau}\right)\right. \\
& \left.+4 \rho \alpha \frac{(1-\tau)\left(1-\tau_{d}\right)^{2}}{(1+r)^{2}} \sigma^{2}\right\} \frac{1}{\Delta^{n}}
\end{aligned}
$$

and

$$
\begin{aligned}
\frac{d \alpha^{r}}{d \tau} & =\left\{\left(1-\tau_{d}\right)(1-\alpha)\left(\frac{z r+1}{1+r} \frac{\partial J^{r}}{\partial \alpha}+\left(-1+\frac{1}{1+r}(\tau r z+\tau)\right) \frac{\partial^{2} J^{r}}{\partial \alpha \partial \tau}\right)\right. \\
& \left.+4 \rho \alpha \frac{(1-\tau)\left(1-\tau_{d}\right)^{2}}{(1+r)^{2}} \sigma^{2}\right\} \frac{1}{\Delta^{r}},
\end{aligned}
$$

where $\Delta^{i}>0$ holds by the second-order condition for the choice of $\alpha^{i}, i=n, r$. The responses in $\alpha^{i}$ are similar in structure to (15) and (16), expect of the last term in curly brackets in (40) and (41). It depicts the insurance effect of a higher corporate tax rate. When $\tau$ rises, a higher fraction of managerial income risk is shifted onto the public budget which lowers the shareholders' cost of using incentive pay.

Next, from (10b) and (11b) we can compute

$$
\frac{\partial^{2} J^{n}}{\partial \alpha \partial \tau}=\left(1-\tau^{d}\right) \frac{z r+1}{1+r}\left(\frac{-g^{\prime \prime}\left(J^{n}\right)}{1+r}\right)^{-1}+\left(-1+\frac{1-\tau_{d}}{1+r}(\tau r z+\tau)\right)\left(\frac{-g^{\prime \prime}\left(J^{n}\right)}{1+r}\right)^{-2} \frac{g^{\prime \prime \prime}\left(J^{n}\right)}{1+r} \frac{\partial J^{n}}{\partial \tau}
$$


and

$$
\frac{\partial^{2} J^{r}}{\partial \alpha \partial \tau}=\left(1-\tau_{d}\right)\left(\frac{z r+1}{1+r}\left(\frac{-g^{\prime \prime}\left(J^{r}\right)}{1+r}\right)^{-1}+\left(-1+\frac{\tau r z+\tau}{1+r}\right)\left(\frac{-g^{\prime \prime}\left(J^{r}\right)}{1+r}\right)^{-2} \frac{g^{\prime \prime \prime}\left(J^{r}\right)}{1+r} \frac{\partial J^{r}}{\partial \tau}\right) .
$$

Both cross derivatives are positive when $g^{\prime \prime \prime}\left(J^{i}\right)$ is not too positive, $i=n, r$. Thus, for many widely used preference functions (including Cobb-Douglas, exponential and iso-elastic utility) $d \alpha^{i} / d z$ is ambiguous in sign. Note, the effect that is captured by the cross derivative is a secondorder effect of $\tau$ on $J$. Consequently, in the absence of the insurance term in (40) and (41), the effect of a higher $\tau$ on perks is signed by the direct, negative effect of $\tau$ on $J$. The result may not hold in the presence of the insurance effect.

\section{A.3 Changes in the dividend tax rate $\tau_{d}$ with retained earnings}

From (14) we can compute

$$
\begin{aligned}
\frac{d \alpha^{r}}{d \tau_{d}} & =\left\{(1-\alpha)\left(-\left(-1+\frac{z r \tau+\tau}{1+r}\right) \frac{\partial J^{r}}{\partial \alpha}+\left(1-\tau_{d}\right)\left(-1+\frac{z r \tau+\tau}{1+r}\right) \frac{\partial^{2} J^{r}}{\partial \alpha \partial \tau_{d}}\right)\right. \\
& \left.+4 \rho \alpha \frac{\left(1-\tau_{d}\right)(1-\tau)^{2}}{(1+r)^{2}} \sigma^{2}\right\} \frac{1}{\Delta^{r}}
\end{aligned}
$$

with $\Delta^{r}>0$. The first-order condition is similar in structure to (14) expect of the last term. It depicts the insurance effect of a higher dividend tax rate. When $\tau_{d}$ rises, a higher fraction of managerial income risk is shifted onto the public budget which lowers the shareholders' cost of using incentive pay.

Using (11b), the cross derivative in (44) is

$\frac{\partial^{2} J^{r}}{\partial \alpha \partial \tau_{d}}=-\left(-1+\frac{z r \tau+\tau}{1+r}\right)\left(\frac{-g^{\prime \prime}\left(J^{r}\right)}{1+r}\right)^{-1}+\left(1-\tau_{d}\right)\left(-1+\frac{\tau r z+\tau}{1+r}\right)\left(\frac{-g^{\prime \prime}\left(J^{r}\right)}{1+r}\right)^{-2} \frac{g^{\prime \prime \prime}\left(J^{r}\right)}{1+r} \frac{\partial J^{r}}{\partial \tau_{d}}$.

Noting that $-1+\frac{1}{1+r}(\tau r z+\tau)<0$ and $\partial J / \partial \tau_{d}>0$, the cross derivative is positive when $g^{\prime \prime \prime}\left(J^{r}\right)$ is not too positive. The condition may not hold for a wide class of preference functions including Cobb-Douglas, iso-elastic, and exponential preferences (for which $g^{\prime \prime \prime}\left(J^{r}\right)>0$ ). Note, the effect that is captured by the cross derivative is a second-order effect of $\tau_{d}$ on $J$. In the absence of the insurance term in (44), the effect of a higher $\tau_{d}$ on perks is signed by the direct, negative effect of $\tau_{d}$ on $J$. This result may not hold in the presence of the insurance effect. 


\section{References}

[1] Aghion, P. and P. Bolton (1992), An incomplete contract approach to financial contracting, Review of Economic Studies, 59, 473-494.

[2] Auerbach, A.J. (1979), Wealth maximization and the cost of capital, Quarterly Journal of Economics, 93/3, 433-446.

[3] Auerbach, A.J. (2002), Taxation and corporate financial policy, in Auerbach, A.J. and M. Feldstein (Eds.), Handbook of Public Economics, Vol. 3, Amsterdam: North-Holland.

[4] Auerbach, A.J., M. P. Devereux and H. Simpson (2010), Taxing corporate income, in: James A. Mirrlees, Stuart Adam, Timothy Besley, Richard Blundell, Steve Bond, Robert Chote, Malcolm Gammie, Paul Johnson, Gareth D. Myles, and James Poterba, eds., Dimensions of Tax Desing: the Mirrlees Review, Oxford University Press, chapter 9.

[5] Auerbach, A.J. and K.A. Hasset (2003), On the marginal source of investment funds, Journal of Public Economics, 87, 205-232.

[6] Boadway, R. and N. Bruce (1984), A general proposition on the design of a neutral business tax, Journal of Public Economics, 24, 231-239.

[7] Bolton, P. and D. Scharfstein (1996), Optimal debt structure and the number of creditors, Journal of Political Economy, 104, 1-25.

[8] Bond, S. and M.P. Devereux (1995), On the design of a neutral business tax under uncertainty, Journal of Public Economics, 58, 57-71.

[9] Bradford, D. F. (1981), The incidence and allocation effects of a tax on corporate distributions, Journal of Public Economics, 15, 1-22.

[10] Chetty, R. and E. Saez (2010), Dividend and corporate taxation in an agency model of the firm, American Economic Journal: Economic Policy, 2, 1-31.

[11] Crocker, K.J. and J. Slemrod (2005), Corporate tax evasion with agency costs, Journal of Public Economics, 89, 1593-1610.

[12] Desai, M., A. Dyck, and L. Zingales (2007), Theft and taxes, Journal of Financial Economics, 84, 591-623.

[13] Desai, M. and D. Dharmapala (2006), Corporate tax avoidance and high-powered incentives, Journal of Financial Economics, 79, 145-179.

[14] Devereux, M.P. and R. De Mooij (2009), An applied analysis of ACE and CBIT reform in the EU, CPB Discussion Paper 128, The Hague.

[15] Devereux, M.P. and H. Freeman (1991), A general neutral profits tax, Fiscal Studies, 12, $1-15$.

[16] Diamond, D. (1984), Delegated monitoring, Review of Economics Studies, L1, 393-414. 
[17] Dittmar, A. and J.Mahrt-Smith (2007), Corporate governance and the value of cash holdings, Journal of Financial Economics, 83, 599-634.

[18] Fazzari, St., G. Hubbard, and B. Petersen (1988), Financing constraints and corporate investment, Brookings Papers on Economic Activity, 141-195.

[19] Gordon, R. and M. Dietz (2009), Dividends and taxes, in: Auerbach, A. and D. Shaviro (Eds.), Institutional Foundations of Public Finance: Economic and Legal Perspectives, Harvard University Press, Cambrdige, MA.

[20] Grossman, S.J. and O.D. Hart (1982), Corporate financial structure and managerial incentives, in: McCall, J.J. (Ed.), The Economics of Information and Uncertainty. University of Chicago Press, Chicago, IL.

[21] Harford, J. (1999), Corporate cash reserves and acquisitions, Journal of Finance, 54, 1969-1997.

[22] Hassett, K. and R. Hubbard (2002), Tax policy and investment, in Auerbach, A. J. and M. Feldstein (Eds.), Handbook of Public Economics, Vol. 3, Amsterdam: North-Holland.

[23] Haufler, A. and G. Schjelderup (2000), Corporate tax systems and cross country profit shifting, Oxford Economic Papers, 52, 306-325.

[24] Holmstrom, B. (1979), Observability and moral hazard, Bell Journal of Economics, 10, 74-91.

[25] Holmstrom, B. and J. Tirole (1997), Financial intermediation, loanable funds, and the real sector, Quarterly Journal of Economics, 112, 663-691.

[26] Institute for Fiscal Studies (1991), Equity for Companies: A Corporation Tax for the 1990s, London.

[27] Jensen, M.C. (1986), Agency costs of free cash flow, corporate finance, and takeovers, American Economic Review, 76, 323-329.

[28] Jensen, M.C. (1993), The modern industrial revolution, exit, and the failure of internal control systems, Journal of Finance, 48, 831-880.

[29] Jensen, M.C. and W.H. Meckling (1976), Theory of the firm: Managerial behavior, agency costs and ownership structure, Journal of Financial Economics, 3, 305-360.

[30] John, K. and S. Kedia (2006), Design of corporate governance: Role of ownership structure, takeovers, and bank debt, mimeo, New York University.

[31] Kaplan, St. and L. Zingales (1997), Do financing constraints explain why investment is correlated with cash flow? Quarterly Journal of Economics, CXII, 169-215.

[32] Kanniainen, V. (1999), Failures in corporate governance: Can the corporation tax improve efficiency?, Finanzarchiv, 56, 310-334. 
[33] Kanniainen, V. and J. Södersten (1994), Costs of monitoring and corporate taxation, Journal of Public Economics, 55, 307-321.

[34] Keuschnigg, C. and E. Ribi (2013), Profit taxes and financing constraints, International Tax and Public Finance, 20, 808-826.

[35] King, M. (1974), Dividend behaviour and the theory of the firm, Economica, 41, 25-34.

[36] Korinek, A. and J. E. Stiglitz (2009), Dividend taxation and intertemporal tax arbitrage, Journal of Public Economics, 93, 142-159.

[37] Richardson, S. (2006), Over-investment of free cash flow, Review of Accounting Studies, 11, 159-189.

[38] Schindler, D. and G. Schjelderup (2012), Debt shifting and ownership structure, European Economic Review, 56, 635-647.

[39] Sharpe, S. (1990), Asymmetric information, bank lending and implicit contracts: A stylized model of customer relationships, Journal of Finance, 45, 1069-1087.

[40] Sinn, H.-W. (1987), Capital Income Taxation and Resource Allocation, North-Holland, Amsterdam.

[41] Sinn, H.-W. (1991a), Taxation and the cost of capital: The 'Old' view, the 'New' view, and Another view, in D. Bradford (Ed.), Tax Policy and the Economy 5, NBER, 25-54.

[42] Sinn, H.-W. (1991b), The vanishing Harberger triangle, Journal of Public Economics, 45, 271-300.

[43] Tirole, J. (2006), The Theory of Corporate Finance, Princeton University Press, Princeton.

[44] US Department of Treasury (1992), Integration of the Individual and Corporate Tax Systems: Taxing Business Income Once, US Government Printing Office, Washington.

[45] Vives, X. (2000), Oligopoly Pricing: Old Ideas and New Tools, MIT Press, Boston, Massachusetts. 